\title{
A POLÍTICA ECONÔMICA DO GOVERNO COSTA E SILVA \\ 1967-1969*
}

\author{
José Pedro Macarini ${ }^{* *}$
}

\begin{abstract}
RESUMO Este artigo busca contribuir para um conhecimento mais aprofundado da política econômica da ditadura militar, concentrando-se num período tratado na literatura de uma forma indevidamente generalista — qual seja, o governo Costa e Silva, caracterizado pelo início da retomada do crescimento e por inflexões na condução da política econômica. Procura-se mostrar que a política econômica do regime experimenta uma importante reorientação em relação ao governo Castello Branco, procedendo-se a uma tentativa de síntese da perspectiva heterodoxa que então tornou-se dominante. Entretanto, é equivocado projetar linearmente sobre todo o período o ideário heterodoxo manifestado durante 1967-1968: com efeito, após o AI-5, durante o ano de 1969 a política econômica obedece a um movimento muito distinto, o qual é objeto de uma detalhada reconstituição.
\end{abstract}

Palavras-chave: Brasil; ditadura militar; política econômica

Código JEL: E650

\section{THE ECONOMIC POLICY OF THE COSTA E SILVA \\ ADMINISTRATION: 1967-1969}

ABSTRACT This article aims to contribute to a deeper understanding of the Brazil's economic policy during the military dictatorship, focusing a period which is treated by the literature in a predominantly general way — the Administration Costa e Silva, characterized by the resumption of the accelerated economic growth but also by important swings in the conduct of economic policy. The article seeks to show that the regime's economic policy exhibits a major change, abandoning the

\footnotetext{
* Artigo recebido em 23 de agosto de 2006 e aprovado em 2 de outubro de 2006.

** Professor Doutor do Instituto de Economia da Unicamp, e-mail: nea@eco.unicamp.br
} 
principles associated with the Castello Branco Administration; a synthesis of the so-called heterodoxy approach which then emerged is delineated. The main argument, however, is that it is a dubious procedure to see all the subsequent conduct of economic policy as a reflection of that new approach - which effectively prevailed during 1967-1968, but after AI-5 reinforced the authoritarian nature of the regime. A carefully detailed description of the conduct of economic policy during 1969 sheds light on this issue.

Key words: Brazil; military dictatorship; economic policy 


\section{INTRODUÇÃO}

A ditadura militar implantada em 1964 colocou no comando da política econômica os melhores representantes do pensamento econômico conservador. O movimento da política econômica, mesmo durante o período de consolidação e fortalecimento do regime, de forma alguma circunscreveuse a um roteiro definido em suas linhas básicas já em 1964. Um retrato mais exato do processo então iniciado deve acentuar as descontinuidades que caracterizaram aquele movimento - o que, entenda-se, não elimina o reconhecimento da existência de elementos de continuidade (dos quais o tratamento dispensado aos salários certamente é o mais conspícuo).

Em sua primeira fase, durante o governo Castello Branco, a política econômica teve na prioridade explícita e enfática conferida ao combate à inflação o seu traço distintivo. Na ótica do PAEG (1964-1966), a crise econômica com que o país se defrontava, manifestada com força em 1963 e inícios de 1964, tinha a sua raiz na inflação. Retomar uma trajetória de desenvolvimento sustentado estaria na dependência de êxito na reversão firme do processo inflacionário: somente assim um acúmulo de disfunções responsáveis pelo declínio da atividade econômica seria eliminado, recriando-se as condições adequadas à maturação plena do potencial de crescimento de uma economia de livre iniciativa. ${ }^{1}$

Para os tecnocratas conservadores a ditadura representou uma oportunidade extraordinária para a aplicação de sua orientação pretensamente racional e eficiente à política econômica, uma vez suprimidas de um golpe quaisquer propostas alternativas enraizadas no nacional-desenvolvimentismo e as possibilidades de mobilização popular em seu apoio. A face austera exibida pelo regime durante o governo Castello Branco por um momento descortinou um horizonte favorável à implementação duradoura desse enfoque para a política econômica, estendendo-se pelo tempo que fosse necessário à obtenção de seus frutos. Contudo, como logo se viu, mesmo os ortodoxos defensores da austeridade tinham o seu apoio pelo regime e pelo empresariado condicionado ao cumprimento de promessas definidas ainda em 1964: uma redução da inflação para 10\% a.a. e a retomada do crescimento a taxas ao redor de $6 \%$ a.a. quando do término do governo Castello Branco. A restauração da lucratividade do capital representava o limite de tolerância para com aquela política econômica. A afirmação de um projeto 
nacional cultivada por frações militares reforçava aquele limite na medida em que o desenvolvimento econômico era uma dimensão essencial. ${ }^{2}$

O diagnóstico da inflação esgrimido pelo PAEG supunha que o crescimento excessivo da demanda agregada era a sua causa essencial — configurando, assim, uma inflação de demanda. Os fatores específicos que suscitavam esse comportamento da demanda residiriam no desequilíbrio orçamentário e na expansão do crédito (impulsionada pelo Banco do Brasil, misto de autoridade monetária e banco comercial), secundados pelo movimento dos salários nominais (também uma componente de custo, a única enfatizada). Daí decorria um programa de ação centrado na redução/eliminação do desequilíbrio orçamentário, controle da expansão monetária e creditícia (estabelecendo-se metas de desaceleração sucessiva de seu crescimento nominal) e contenção dos reajustes salariais nominais dos trabalhadores assalariados. Sua execução concreta, não isenta de contradições, caracterizou-se por uma progressiva aproximação das metas operacionais, culminando no ano de 1966 quando sua aplicação revestiu-se de notável rigor. Paradoxalmente isso traduziu-se em seu fracasso aos olhos do regime e na decisão de reorientar a política econômica tomada pela administração empossada em 1967 com Costa e Silva. ${ }^{3}$

Tem início, então, um período inequivocamente marcado pela heterodoxia na condução da política econômica. A literatura dedicada ao tema freqüentemente tendeu a tratar em bloco todo o período que se prolonga até o final do governo Médici, como se tivesse existido uma continuidade básica na aplicação do novo ideário imperante desde 1967. Ao assim proceder perderam-se de vista aspectos importantes do movimento da política econômica - na verdade, este continuou a exibir mudanças significativas ao ponto de permitir apontar a eclosão de outras inflexões. Uma das mais expressivas ocorreu como desdobramento imediato da mudança de conjuntura política assinalada pelo AI-5, tornando o último ano do governo Costa e Silva palco de um novo experimento ortodoxo de combate à inflação sob o comando de Delfim Netto. O episódio teve curta duração, pois com a "eleição" de Médici no final de 1969 mudanças substantivas seriam implementadas, inaugurando uma outra fase da política econômica.

Este artigo concentra-se no exame da política econômica do governo Costa e Silva, procurando mostrar a existência de duas fases com caracte- 
rísticas distintas: heterodoxa, em 1967-1968, quando afastou-se substantivamente da linha de ação anterior do PAEG; ortodoxa, em 1969, quando a sua execução perseguiu explícita e efetivamente um "ataque mortal” à inflação. O artigo compõe-se de três seções, além desta introdução. A seção 1 reconstitui atentamente o diagnóstico heterodoxo formulado por Delfim Netto em 1967-1968 e procede a uma sumária reconstituição da execução da política econômica, ressaltando o contraste com o PAEG. A seção 2 faz uma detalhada reconstituição da condução da política econômica no ano de 1969, procurando deixar evidenciada a mudança de curso em relação ao biênio anterior. A seção 3 desenvolve algumas considerações finais.

\section{A POLÍTICA ECONÔMICA DURANTE A FASE ANTERIOR AO AI-5: A HETERODOXIA EM AÇÃO}

Encerrado o triênio de aplicação do PAEG, o grau de insatisfação com seus resultados é veiculado explicitamente nos documentos produzidos no âmbito do Ministério da Fazenda. No início de 1967 Delfim Netto levantava três indagações sobre o curso da política econômica, todas constrangedoras para o grupo conservador ortodoxo que saía de cena:

Primeiramente, por que estamos ainda diante de um processo inflacionário bastante intenso, apesar do Governo ter colocado em prática uma política econômica caracterizada por um rígido controle de demanda? Em segundo lugar, quais as causas das reduções periódicas do nível de atividade que têm caracterizado a nossa economia nos últimos anos? Finalmente, de que forma será possível compatibilizar o objetivo de manutenção de taxas de inflação dentro de limites razoáveis com o de plena utilização dos fatores e retomada do desenvolvimento? ${ }^{4}$

A resposta a tais indagações conduzia à rejeição do diagnóstico de inflação de demanda formulado pelo PAEG e que norteara a execução da política econômica durante todo o período - sobretudo em 1966, quando a política monetária por fim lograra cumprir praticamente à risca a meta estipulada para o crescimento da oferta de moeda. A inflação brasileira era percebida como um fenômeno complexo, de múltiplas causas e, aspecto essencial, de natureza cambiante conforme o desenrolar da conjuntura. Delfim o diz sem deixar margem para dúvidas:

Uma análise mais cuidadosa mostra que a inflação brasileira recente não pode ser explicada em termos de esquemas puros de inflações de demanda 
ou de custos, mas que estas duas formas de tensões se alternam no tempo, sendo possível localizarem-se fases em que predominaram os estímulos da demanda ou o crescimento dos custos. Na verdade, a inflação de custos estava latente na economia, porém oculta pelo crescimento da demanda, e somente emergiu quando foi feito o controle da demanda. ${ }^{5}$

Aí residia a resposta para as perplexidades do regime. A rígida ortodoxia do governo Castello Branco, impossibilitando perceber a mudança de natureza da inflação, tendeu a perder a eficácia, tornando-se causa da continuidade da crise e do processo inflacionário. Com efeito, algumas das tensões de custo eram engendradas pela própria política econômica, particularmente a elevação das taxas de juros em 1966 (explicada pela rigidez da política monetária e pela reativação do endividamento público); adicionalmente, ao precipitar uma crise de estabilização, suscitava tensões de custo associadas ao crescimento da capacidade ociosa (implicando maiores custos médios na indústria). Tensões de custo oriundas da inflação "corretiva", a permanência de expectativas inflacionárias e a alta dos preços agrícolas (especialmente forte em 1966) completavam o quadro no tocante à resistência demonstrada pelo processo inflacionário. Contrastando acentuadamente com a retórica do regime praticada pelos governos seguintes, Delfim Netto afirmava categoricamente no início do governo Costa e Silva:

Atualmente é difícil aceitar-se que um excesso de demanda possa ser a explicação única para a inflação brasileira. A existência simultânea de elevação geral de preços e estagnação demonstra uma inconsistência no diagnóstico da inflação de demanda, cuja característica principal seria o aumento de preços acompanhado de níveis elevados de utilização da capacidade produtiva. ${ }^{6}$

Numa conjuntura de custos crescentes, um controle rígido da demanda agregada centrado na restrição da oferta de moeda e crédito (e eventualmente agravado pela incidência da política fiscal e da política salarial) levaria à queda dos níveis de produção e emprego - uma reação natural das empresas defrontadas com uma liquidez bastante precária (como se observou no final de 1966). O movimento da economia no triênio 1964-1966, experimentando duas curtas recessões, aproximou-se do perfil stop and go, refletindo em parte as próprias flutuações da política monetária. A continuidade de uma conjuntura com essas características impediria a retomada do desenvolvimento, pois tenderia a manter deprimido o ritmo do investimento na economia. ${ }^{7}$ 
O contraste com a ortodoxia do PAEG é evidente. Deslocando o marco de avaliação da política econômica para o longo prazo, a crise de estabilização era vista com naturalidade pelos economistas da corrente ortodoxa, conforme sintetizado no aforisma de Simonsen de que as recessões que acompanhavam a desinflação podiam ser vistas como a aplicação do princípio "recuar para saltar melhor". Nessa perspectiva, não apenas nada haveria de errado com a execução do PAEG em 1966 como, inclusive, suas diretrizes deveriam ser continuadas no governo seguinte de forma a lograr a estabilização, ainda que com certo atraso em relação às expectativas iniciais. Já para Delfim, as oscilações conjunturais experimentadas pela economia, afetando negativamente os determinantes das decisões de investimento (a taxa de lucro esperada, a disponibilidade de fundos, expectativas de ampliação da demanda futura), comprometiam a própria possibilidade de retomar um desenvolvimento sustentado. ${ }^{8}$ Assim, o objetivo prioritário colocado pela nova administração foi a estabilização do crescimento industrial em torno de sua tendência de longo prazo, erradicando o stop and go responsável pelo fracasso em conciliar a desinflação progressiva com a retomada segura do desenvolvimento econômico. Mas não se entenda que o objetivo da redução da inflação tenha sido abandonado, pois Delfim compartilhava a percepção ortodoxa de que a inflação tem efeitos contraproducentes para o desenvolvimento. ${ }^{9}$ Isso o conduzia a sintetizar nos seguintes termos a sua proposta de política econômica:

Tanto o combate à inflação quanto a estabilização da produção industrial em torno de seu padrão normal de longo prazo apresentam-se portanto como pré-condições à retomada do desenvolvimento econômico. A política econômica executada em 1967 e a delineada para 1968 são calcadas nos objetivos de redução das taxas de inflação, estabilização do nível de atividade em torno de sua tendência de longo prazo e retomada do desenvolvimento acelerado. $^{10}$

O cerne da questão, entretanto, diz respeito ao timing da decisão em favor da "estabilização do crescimento", quando a taxa de inflação ainda era muito elevada. A rationale teórica esconde o essencial, qual seja, o imperativo de uma mudança de orientação posto pelas condições políticas vigentes naquela conjuntura. ${ }^{11}$ Tal mudança traduziu-se numa clara inflexão no movimento da política econômica inaugurado em 1964. Com efeito, a sua 
execução em 1967-1968 exibe um perfil substancialmente distinto em comparação com o observado durante a aplicação do PAEG.

No caso da política fiscal, a mudança mais sensível ocorreu em 1967, quando o déficit orçamentário cresceu expressivamente, alcançando 1,7\% do PIB (em 1966, ele representara 1,1\% do PIB). É verdade que em parte isso se deveu a um processo espontâneo resultante do expediente utilizado pela gestão anterior de transferir dispêndios de 1966 para o ano seguinte (o que, aliado à recessão, fez com que aproximadamente $80 \%$ do déficit orçamentário se concentrasse no primeiro trimestre de 1967). Contudo, não houve qualquer esforço nos trimestres seguintes no sentido de compensar aquele movimento, aceitando-se tranqüilamente a reversão da tendência perseguida com sucesso pelo PAEG. Ela era inclusive justificada como uma desejável ação compensatória da política fiscal numa conjuntura em que o setor privado encontrava-se deprimido. ${ }^{12}$

Ainda mais revelador da nova postura assumida pelas autoridades econômicas foi o recurso a alguns expedientes que implicaram renúncia de receita num primeiro momento (jogando para um futuro indefinido o equilíbrio orçamentário perseguido na gestão anterior). Por um lado, elevou-se o teto de isenção sobre o imposto de renda das pessoas físicas, resultando em um ganho aproximado de 5\% para os salários reais das faixas salariais favorecidas. Como se sabe, essa é uma típica medida de estímulo à reativação da demanda de consumo. De outro lado, o governo determinou o alongamento transitório dos prazos para o recolhimento do IPI, passando a dispor de 30 a 45 dias, em vez de ser feito no ato do faturamento. Dessa forma disponibilizava-se ao setor industrial uma apreciável soma de recursos para capital de giro a um custo praticamente nulo. No contexto recessivo dos primeiros meses de 1967, a rationale dessa medida estava voltada muito mais ao objetivo de dotar o sistema empresarial de flexibilidade, capacitando-o a responder de imediato à reativação da demanda, numa situação emergencial em que escasseavam os títulos exigidos pelo sistema bancário para a realização das operações de crédito (por isso mesmo o alongamento tinha uma vigência limitada). ${ }^{13}$

Não resta dúvida que a política fiscal foi manejada em 1967 tendo por objetivo prioritário induzir a reativação da economia. Em 1968, porém, salvo numa perspectiva de curtíssimo prazo (como valorizada por Delfim), 
ela dificilmente teve um papel expressivo na manutenção do crescimento, posto que o déficit orçamentário declinou para 1,2\% do PIB, apenas ligeiramente maior que o obtido pelo PAEG em 1966. Ainda assim é notável o afastamento em relação à ortodoxia do PAEG: durante dois anos seguidos a política econômica não vê urgência nenhuma na busca do equilíbrio orçamentário, não avançando nada nesse sentido.

No âmbito da política monetária, a mudança é ainda mais marcada, observando-se uma vigorosa e continuada expansão real da oferta de moeda e crédito. Inicialmente a liberalidade da política monetária é justificada com o argumento de que a velocidade renda da moeda tende a declinar com a desaceleração da inflação, reduzindo pois o potencial inflacionário da expansão monetária. Mas em 1968 o patamar inflacionário permaneceria inalterado (chegando a aumentar um pouco no caso do IPA), sem que a política monetária sofresse qualquer correção. O crescimento do crédito bancário ao setor privado, com o Banco do Brasil à frente, foi nada menos que extraordinário, beirando os 30\% a.a. em valor real. Tenha-se em conta, no caso do Banco do Brasil, o seu papel de suporte à agricultura - o que, aliado a condições climáticas favoráveis (em 1967), propiciou uma expansão do setor reduzindo as pressões de custo aí originadas (as quais foram particularmente fortes no último ano do PAEG). É claro que essa política monetária foi instrumental para a recuperação que teve início em abril de 1967, engendrando uma demanda crescente de liquidez e crédito para capital de giro. Como se sabe, entretanto, a liderança da recuperação coube aos bens de consumo duráveis e nesse sentido não se deveu a um processo mecânico de condução da política macroeconômica, estando ligada a processos mais amplos como a reconcentração de renda e a expansão do crédito direto ao consumidor. E a política delfiniana não deixou de imprimir sua marca nesse processo ao promover a especialização das financeiras no CDC, consolidando aquele mecanismo criado pelas reformas de Campos-Bulhões.

Por outro lado, tampouco deve ser negligenciado o fato de que a eficácia dos instrumentos de controle monetário nesse período era reconhecidamente limitada, de forma que em parte a expansão monetária foi um fato consumado à revelia das intenções. Isso é admitido pelo presidente do Banco Central, que aponta as oscilações no movimento de capitais vinculados à expectativa de desvalorização cambial — de maio a junho de 1968 a situa- 
ção teria sido de "corrida no mercado de câmbio" desatada pelas "notícias de uma nova desvalorização cambial" - como responsáveis pela "continuidade do ritmo exagerado da expansão creditícia”. Mas o importante é indagar o porquê da complacência exibida pelas autoridades em face dessa situação. A resposta — dada a impossibilidade de executar uma sintonia fina, qualquer tentativa de correção daqueles movimentos recriaria o stop and go da gestão anterior - confirma a efetiva mudança de prioridades da política econômica. ${ }^{14}$ Essa foi uma das razões determinantes da adoção do regime de minidesvalorizações cambiais a partir de agosto de 1968 .

No tocante ao combate à inflação, com certeza o desempenho de 1967 se deveu basicamente ao comportamento dos preços agrícolas numa conjuntura de expansão da oferta. Entretanto, coerentemente com o novo diagnóstico, buscou-se reduzir as taxas de juros. Isso foi feito de forma direta, no caso dos empréstimos do Banco do Brasil, e por meio de tentativas de "acordos de cavalheiros" com a banca privada, culminando na fixação de um teto, no caso das operações de desconto dos bancos comerciais, determinada pela Resolução 72, de novembro de 1967 (com resultados práticos no mínimo duvidosos). Ademais, abandonou-se a política do PAEG de financiamento "não inflacionário" do déficit orçamentário: já em 1967 as emissões de ORTN cobriram menos da metade do déficit (em comparação com 100\% em 1966) e em 1968 tão-somente 14\%, objetivando, dessa forma, diminuir a pressão sobre o setor privado. Mas o elemento mais significativo da política de combate à inflação foi a adoção da prática de acompanhamento dos preços industriais que levou à instituição do CIP em 1968. Essa medida representou o reconhecimento tácito da dominância de condições oligopólicas no processo de formação de preços, as quais podem dar margem a pressões inflacionárias autônomas originárias de aumentos arbitrários no mark-up, seja em razão das estratégias das grandes empresas, seja pelo efeito das expectativas inflacionárias. ${ }^{15}$

O período também é caracterizado pela introdução das primeiras medidas mais agressivas de estímulo às exportações (isenção de impostos indiretos, minidesvalorizações cambiais). Não seria correto, porém, considerar que a implementação do "modelo exportador" já se constituísse numa peça essencial da política econômica: na verdade, tal somente ocorreu um pouco mais à frente, durante o governo Médici. No período 1967-1968, 
não apenas o "modelo exportador" não é oferecido como opção alternativa de uma estratégia de desenvolvimento, como também se nota a influência de elementos da tradição estruturalista nas reflexões realizadas no âmbito do Planejamento, que ganharam expressão no PED (Programa Estratégico de Desenvolvimento) lançado em junho de 1968.

\section{A POLÍTICA ECONÔMICA EM 1969: RETORNO À ORTODOXIA?}

\subsection{Redefinição das prioridades}

O desempenho da economia brasileira no ano de 1968 fora, de vários pontos de vista, extremamente satisfatório. O setor industrial, segundo apontavam as primeiras estimativas da época, desfrutara de uma excelente performance: sua taxa de crescimento teria se aproximado de 14\%, enquanto os níveis alcançados pelo emprego industrial revelavam um quadro muito promissor, tendo suplantado em todos os meses desse ano quaisquer outras marcas verificadas desde 1964. O notável desempenho do setor industrial já desvelava o essencial do novo padrão de crescimento: a indústria automobilística inicia em 1968 o seu ciclo de recordes sucessivos de produção (mais de 270 mil unidades produzidas, contra 225 mil em 1967) e a indústria da construção civil experimenta substancial ativação (expressão do incremento da demanda habitacional ou da maior expansão do gasto público). Em resposta àquele desempenho dos dois setores líderes e à reativação do investimento público (em especial de algumas empresas públicas), o setor de bens intermediários também cresceria expressivamente (a siderurgia cresce ao redor de 16\% em 1968; e o setor de materiais de construção chega inclusive a ser surpreendido pela grande expansão da demanda, ocorrendo insuficiência de oferta de alguns produtos, como o cimento, por exemplo). E até mesmo a indústria têxtil, um dos setores mais penalizados pela crise econômica, conseguiria compensar parcialmente as agruras vividas nos anos anteriores. Mas a retomada não era apenas dos níveis de produção corrente. Existiam claros indícios de que também os investimentos industriais começavam a esboçar uma recuperação, fato dos mais auspiciosos do prisma da consolidação do crescimento. Por outro lado, as exportações exibiam os primeiros sinais do futuro boom exportador, tendo experimentado o seu primeiro grande salto ao atingir a marca de US\$ 1,8 bilhão (após mais de 15 anos de 
literal estagnação), enquanto as reservas internacionais, pela primeira vez em vários anos, logravam atingir um modesto incremento, pouco superior a US\$ 100 milhões. ${ }^{16}$

Heterodoxia na condução da política econômica e reativação do crescimento econômico pareciam caminhar pari passu. Estranhamente, essa não seria uma apreciação generalizada na entrada de 1969. O discurso delfiniano reflete a existência de um "estado de espírito" marcado pela dúvida, pela incerteza ou mesmo pela insatisfação, afetando o regime e mantendo subjudice a execução da política econômica. Uma componente crucial dessa atmosfera originou-se no dissenso interno ao estamento militar. Com efeito, o período é de fermentação de dissidências nacionalistas que se caracterizam, no plano da política econômica, pela pregação de um projeto nacional — na verdade, um projeto de "redenção" nacional, capaz de guindar o Brasil ao universo dos desenvolvidos em um horizonte de tempo aceitável. Em meio a um quadro de incerteza, ou mesmo desconfiança, o discurso delfiniano busca enfatizar o difícil que é alcançar taxas de crescimento que não vão além da média histórica brasileira, numa demonstração de modéstia que contrasta com a postura adotada durante todo o governo Médici (1970-1973). ${ }^{17}$

O movimento imprimido à política econômica após a edição do AI-5 sugere que mesmo as autoridades econômicas não estavam plenamente seguras da solidez da recuperação: os fantasmas da longa crise 1963-1967 continuavam a rondar a imaginação, a percepção do "milagre" não tinha ocorrido ainda. Sim, porque ao mesmo tempo em que se supervalorizava um crescimento de $6 \%$ a $7 \%$ ao ano, sem atrever-se a projetar nada mais ambicioso, propunha-se o abandono da opção de convivência com a inflação, numa clara indicação de que os resultados até então obtidos não eram avaliados tão positivamente.

Convém insistir nesse ponto. Em 1967, a política econômica do regime declarava: houve um erro na avaliação da conjuntura e na execução da política econômica durante o período anterior. A inflação tornara-se predominantemente de custos e a aplicação de uma inadequada política de estabilização não apenas realimentou o processo inflacionário como também lançou a economia em uma recessão. Mudemos as prioridades, a partir de um diagnóstico mais adequado à realidade, sem o que não teremos tão cedo a retomada do desenvolvimento nem tampouco a vitória sobre a inflação. 
Assim, a inflação tornar-se-ia uma preocupação subordinada. Em dezembro de 1968, a retomada do desenvolvimento já estava se cristalizando: todos os dados disponíveis o indicavam. No entanto, uma vez ampliado o espaço de manobra da política econômica graças ao AI-5, esta de imediato procede a uma nova revisão de prioridades, reelegendo a inflação como o inimigo principal. Minha hipótese é que tal movimento deve ser lido como um sinal de vacilação dos condutores da política econômica, expressão da existência de uma forte insatisfação diante dos êxitos já alcançados e, sobretudo, insegurança quanto aos caminhos percorridos pela economia. A paralisação na tendência declinante da inflação levantaria dúvidas em torno da qualidade da política econômica em curso e, por extensão, sobre o caráter sustentado da retomada. É evidente que tais dúvidas não são vocalizadas dados o fechamento político, a ideologia do autoritarismo e a manutenção da mesma equipe econômica. Ademais, o relativo insucesso da política econômica até então pode ser implicitamente atribuído às restrições políticas pré-AI-5, que conspiravam contra o exercício da racionalidade.

O diagnóstico que fundamentara em suas grandes linhas a política econômica no biênio 1967-1968 é agora posto à margem — ainda que se veja preservado como passagem retórica. De heterodoxamente expansiva, perseguindo a estabilização do crescimento, a política econômica assume em 1969 traços explicitamente restritivos, voltada para o propósito de impor substancial redução à taxa de inflação. A possibilidade mesma de um crescimento econômico sustentado é atrelada à consecução do êxito no combate à inflação. ${ }^{18}$

Não resta dúvida que em 1969 o norte da política econômica foi a busca da estabilidade monetária, conforme tornado claro por uma pequena amostra de declarações oficiais. Delfim Netto anunciaria o novo curso da seguinte forma:

O importante, na atual fase do combate à inflação, é que o ímpeto altista foi controlado simultaneamente com uma expansão na atividade econômica. Seria o caso de manifestarmos satisfação pela performance, mas esta postura é falsa, porque uma inflação de $20 \%$ ou mais ao ano é também um recorde, mas negativo.

Já demonstrei em algumas ocasiões, com dados extraídos da história recente da economia brasileira, que a uma taxa inflacionária menor tem correspondido um crescimento maior e mais constante. E vice-versa. 
Se pudemos crescer $6 \%$ com inflação, vamos correr o risco de crescer $12 \%$ sem a companhia da inflação. Nas presentes circunstâncias, é possível desencadear em 1969 um ataque frontal à inflação — com muito menos sacrifícios do que em qualquer outra ocasião, próxima ou remota. Seria um crime deixar a tentativa para outra ocasião (ou para outra geração). ${ }^{19}$

O ministro Hélio Beltrão também procuraria explicar os novos rumos:

Qual é a perspectiva que se abre agora ao Governo? É a de assestar um golpe mortal na inflação. É isto que nos preocupa hoje (...).

Até agora o nosso combate teve que ser dosado porque havia o risco de se enfrentar a inflação de maneira tão drástica que isso viesse a produzir a estagnação, a paralisação da economia. E a esse preço nós não queríamos combater a inflação. Mantivemos a inflação sob controle. Agora temos de derrotá-la e podemos derrotá-la, porque ela decorre principalmente do déficit do Governo e do custo do dinheiro, do preço dos juros. Queremos atacar a inflação nessas duas frentes de uma maneira bastante rigorosa. (...)

A taxa de crescimento de 68 foi a maior taxa de crescimento nos últimos 8 anos, e indica que retomamos os níveis de crescimento acelerado e desta vez, auto-sustentáveis, sem risco de colapso e por isso podemos tentar um golpe à inflação que não seja mortal para o desenvolvimento.

Podemos enfrentar a inflação tranqüilos agora, porque a economia está recuperada, todos os índices foram positivos, o aumento de empregos foi impressionante em $1968(\ldots) .^{20}$

E, para que não paire nenhuma dúvida, eis o que se sustentava no preâmbulo de um documento contendo a primeira importante coleção de medidas tomadas dentro do novo espírito da política econômica:

A partir da segunda quinzena de dezembro de 1968, o Governo Federal iniciou nova escalada na execução do Programa Estratégico, através de um conjunto de medidas destinadas a queimar etapas na consecução de suas metas.

Tais medidas (...) destinam-se, basicamente, a fortalecer a empresa privada nacional e reduzir o déficit de caixa e aumentar a eficiência do setor público. Servem simultaneamente aos objetivos de assestar poderoso golpe contra a inflação e elevar a taxa de crescimento do PIB, em 1969. (...)

Em 1967 e 1968, dentro da estratégia desde o início adotada pelo atual Governo, foi possível impulsionar a economia brasileira para novo patamar de crescimento, reduzindo consideravelmente a taxa de inflação. A relativa estabilidade de preços, perseguida como condição do crescimento acelerado e auto-sustentado que constitui a idéia mestra do Programa Estratégico, 
ainda estava a certa distância. Pretende-se, agora, encurtar rapidamente essa distância, avançando novo passo na expansão dos níveis de produção, emprego e investimentos. ${ }^{21}$

Dessa forma, vencida a restrição representada pela recessão aberta do início de 1967 e liberada das pressões de interesses contraditórios afloradas durante a fase liberal de 1967-1968, a política econômica retorna ao objetivo central colocado pelo regime desde a sua implantação. Assestar um "golpe mortal” (na definição de Hélio Beltrão) no processo inflacionário erigia-se em objetivo prioritário precisamente porque condição sine qua non para a consolidação da retomada. Sem a estabilidade da moeda, é impossível a estabilidade do desenvolvimento. Qual a diferença com relação à perspectiva do triênio Campos-Bulhões? ${ }^{22}$ Indagação tanto mais pertinente quando se tem em conta que o déficit orçamentário volta a ser apontado como "o principal foco gerador de pressão inflacionária”, alertando-se para os riscos inflacionários da "expansão imoderada dos meios de pagamento" e defendendo-se a "contenção do crédito". ${ }^{23}$

O "golpe mortal" na inflação não deveria engendrar nenhuma crise de estabilização, projetando-se a continuidade do crescimento: as previsões oficiais apontavam um crescimento do PIB da ordem de 7\% a 8\% em 1969. Em nenhum momento se imaginou tomar a intensificação do crescimento geradora da Nação Potência como tarefa da política econômica, diferentemente do que se observou a partir da posse de Médici. Tampouco a idéia de um "modelo exportador" tem importância nesse momento, não se alimentando grandes ambições em relação ao desempenho das exportações. ${ }^{24}$

\subsection{A execução da política econômica em 1969}

\subsubsection{Primeiro round: redução do déficit orçamentário e fortalecimento}

da estrutura de capital da empresa nacional

Os esforços de contenção do déficit orçamentário traduziram-se em três medidas:

(1) Decreto $n^{0}$ 63.946, de 30/12/68, visando alcançar uma contenção no nível das despesas correntes. Dentre seus vários dispositivos destacam-se: a determinação de vedar, no primeiro semestre de 1969, o ingresso de pessoal, a qualquer título, na Administração Direta e nas 
Autarquias, inclusive sob a forma de prestação de serviços mediante recibos; e a proposta de redução progressiva, até alcançar no mínimo 10\% (no $4^{\circ}$ trimestre de 1969, tomando-se por base a folha de pagamento de novembro de 1968) da despesa global de pessoal no âmbito de cada Ministério. O efeito esperado desse decreto seria uma economia de despesa ao redor de Cr\$350 milhões. ${ }^{25}$

(2) Decreto $\mathrm{n}^{0} 64.010$, de 21/01/69, estabelecendo para o orçamento de 1969 um montante máximo de despesa de caixa da ordem de Cr\$14.229 milhões e uma previsão de receita em torno de Cr\$13.125 milhões. Tal orçamento implicava uma redução de gastos muito concentrada em projetos do Ministério do Interior, afetando os interesses regionais. ${ }^{26}$

(3) Ato Complementar 40, de 30/12/68, determinando a redução à metade do Fundo de Participação dos Estados e Municípios. Essa foi certamente a medida de maior efetividade, projetando uma economia de Cr\$ 600 milhões e uma estimativa de redução do déficit orçamentário para Cr\$ 528 milhões — de longe, o menor déficit da política econômica da ditadura.

O Fundo de Participação originou-se das discussões que levaram à Reforma Tributária de 1966, tendo suas disposições consolidadas no artigo 26 da Constituição de 1967. Esse artigo estabelecia que, do produto da arrecadação federal dos impostos sobre rendas e proventos e sobre produtos industrializados, $80 \%$ constituiriam receita da União, 10\% receita do Fundo de Participação dos Estados e os restantes 10\% constituiriam receita do Fundo de Participação dos Municípios. Ademais, no tocante à participação dos municípios, o Ato Complementar 35, de 28/01/67, estipulou a seguinte distribuição da receita do Fundo: 10\% seriam destinados aos municípioscapitais e os restantes $90 \%$ aos demais municípios.

O mecanismo do Fundo de Participação tinha claramente um objetivo redistributivo de renda. Assim, por exemplo, a parcela destinada aos municípios-capitais deveria ser distribuída proporcionalmente a um coeficiente individual de participação resultante do produto de dois fatores:

(a) fator representativo da população, estabelecido por meio da participação percentual da população da capital considerada em relação ao total da população de todas as capitais do País; 
(b) fator representativo do inverso da renda per capita do respectivo estado. Da mesma forma, a distribuição da parcela correspondente aos outros municípios far-se-ia com base na atribuição a cada município de um coeficiente individual de participação determinando a categoria do município segundo o seu número de habitantes. Quanto aos estados, a distribuição do Fundo era feita levando em conta um critério de proporcionalidade à superfície territorial e aos coeficientes individuais de participação; estes coeficientes, por seu turno, são calculados de modo inversamente proporcional à renda per capita $\mathrm{e}$ diretamente proporcional à população de cada estado.

Os recursos do Fundo de Participação beneficiavam especialmente os estados das regiões Norte, Nordeste e Centro-Oeste. Por exemplo, em 1968 o FPE, como proporção da receita própria, alcançou 35,4\% na Bahia, 67,9\% no Ceará, 74,3\% no Amazonas, 107,8\% no Maranhão, 119,8\% no Piauí; em contrapartida, a cifra correspondente para São Paulo foi de $0,49 \%$. No caso dos municípios-capitais, a perda de receita provocada pela Reforma Tributária foi de tal proporção para as regiões Norte e Nordeste que o mecanismo do Fundo de Participação se revestiu de um papel vital. Ainda assim, a receita efetiva per capita em termos reais exibe um declínio em várias capitais no biênio 1967-1968 em relação a 1965-1966.

O Ato Complementar 40 reduziu para $12 \%$ da receita de IR e IPI as transferências para estados e municípios, sendo 10\% correspondentes ao FPEM e 2\% um Fundo Especial dependente de futura regulamentação. Ademais, eliminava o caráter automático que caracterizou originalmente o FPEM, perseguindo-se um controle quase total por parte da União sobre a alocação desses recursos. Com efeito, a nova regulamentação exigia que estados e municípios apresentassem programas e projetos, subordinava a aplicação dos recursos a diretrizes e prioridades estabelecidas pelo Governo Federal e condicionava a entrega do FPEM à vinculação de recursos próprios para os projetos a serem beneficiados, dentre outros dispositivos. ${ }^{27}$

A preocupação com o déficit orçamentário e a inflação não impediu que, amparados na diretriz de fortalecimento do setor privado, uma série de estímulos e concessões de ordem fiscal fossem dados ao empresariado. Eles se traduziram nas seguintes medidas: 
(1) Decreto-lei no 401, de 30/12/68: reduziu o imposto de renda na fonte incidente sobre bonificações e dividendos de ações ao portador de $40 \%$ para $15 \%$ no caso das sociedades anônimas de capital aberto (25\% no caso das demais sociedades anônimas); concedeu isenção de imposto de renda, válida até 30/06/69, às empresas que decidissem incorporar reservas ao seu capital; permitiu às empresas o abatimento da importância correspondente à manutenção do capital de giro no cálculo do imposto de renda devido (o alcance dessa benesse seria restringido pelo decreto-lei no 433 , de 22/01/69, com base no temor de que seu efeito sobre a arrecadação viesse a ser exagerado: assim, aquele dispositivo não poderia implicar redução superior a $20 \%$ do imposto que seria devido sem o abatimento referente à manutenção do capital de giro próprio). ${ }^{28}$

(2) Decreto-lei no 403, de 30/12/68, disciplinando a tributação dos títulos de renda fixa: tornou obrigatório o imposto de renda na fonte (dessa forma fechando brechas na legislação utilizadas para a evasão fiscal); estabeleceu alíquotas de imposto de renda diferenciadas conforme o prazo de vencimento, variando de $10 \%$ para os títulos de 180 dias a $4 \%$ para os de prazo igual ou superior a 720 dias; prorrogou o esquema de estímulos ao mercado de capitais instituído pelo decreto-lei $n^{\circ} 157$, ampliando de $10 \%$ para $12 \%$ o abatimento do imposto de renda permitido às pessoas físicas e admitindo, pela primeira vez, que uma parte dos recursos aí originados fosse destinada à aplicação direta na Bolsa de Valores.

(3) Decreto-lei no 427, de 08/01/69, voltado estritamente ao objetivo de desestimular o mercado paralelo, responsável pelo desvio de uma parcela expressiva de recursos dos condutos normais do sistema financeiro (e da incidência do imposto de renda). Com esse fim estabeleceu a obrigatoriedade do registro, no prazo de 60 dias (a contar da data de publicação), de todas as notas promissórias e letras de câmbio até então emitidas, sob pena de nulidade desses títulos de crédito. Enquanto que os títulos emitidos a partir da data de publicação do decreto deveriam fazê-lo, sob a mesma pena de nulidade, no prazo de 15 dias a contar de sua emissão. As notas promissórias e letras de câmbio que deixassem de ser levadas a registro nos prazos es- 
tipulados não poderiam ser protestadas nem facultariam a execução da dívida que representassem. Estabeleceu ainda a obrigatoriedade de os Cartórios de Notas comunicarem ao Ministério da Fazenda os contratos, escrituras e outros documentos envolvendo transações de valor superior a 600 vezes o maior salário mínimo vigente no País. ${ }^{29}$

Esse conjunto de medidas atuaria da seguinte forma. A expressiva redução do déficit orçamentário levaria a uma diminuição sensível da tensão inflacionária existente na economia. Essa, entretanto, seria tão-somente uma condição necessária para o sucesso na redução da inflação, devendo ser complementada pela execução de uma política monetária que evitasse uma expansão irrefreada da oferta de moeda e do crédito ao setor privado, como foi observado em 1967-1968. Daí a importância das várias concessões fiscais ao empresariado: estas, ao reforçarem a capacidade de geração interna de recursos, facilitariam a busca da disciplina monetária e, quem sabe, ensejando algum alívio nas taxas de juros. Numa perspectiva de longo prazo, esses mesmos efeitos seriam assegurados por meio da desejada expansão do mercado de capitais, reduzindo o grau de dependência do crédito bancário. ${ }^{30}$

Essas medidas receberam aplauso generalizado do empresariado, especialmente da indústria e do segmento identificado com o nascente mercado de capitais. Mas elas não refletiram de forma alguma um consenso no âmbito do regime: o ministro do Interior, general Albuquerque Lima, que exercia uma liderança junto à corrente nacionalista do Exército, se opôs com veemência à nova orientação da política econômica pós-AI-5, abandonando o governo em nome de "outros princípios, outras idéias" que, agora, não mais encontravam guarida em face da "verdadeira escalada dos grupos econômicos poderosos (...) sobre as áreas de influência e de decisão na formulação da política econômico-financeira do País" ${ }^{31}$ A resposta de Delfim Netto, agora numa posição sumamente fortalecida, é típica da postura tecnocrata: ele evocaria o "realismo e a racionalidade", os "dois fatores extraordinariamente escassos neste País", para justificar o acerto da política econômica. ${ }^{32}$

\subsubsection{Segundo round: tabelamento das taxas de juros}

A preocupação explícita com os efeitos negativos das altas taxas de juros foi uma característica da política econômica desde 1967. No biênio pré-AI-5, porém, a atuação do governo nesse campo foi relativamente branda e, so- 
bretudo, acompanhada de resultados notoriamente insuficientes. No início de 1969, a situação se apresentaria agravada: é impossível precisar o nível então vigente das taxas de juros, mas o jornalismo econômico da época veiculava a opinião unânime de que ele seria muito superior a 2,0\% a.m. (aproximadamente o teto perseguido há algum tempo pela política econômica). Delfim admitiria em dezembro de 1968: "A questão cruciante para as empresas, neste limiar de 1969, continua sendo o custo do dinheiro, mas não há de ser através da redução dos níveis de depósito compulsório que nós vamos corrigir as distorções institucionais do mercado financeiro". ${ }^{33}$

A resistência dos juros à baixa - numa conjuntura em que pelo menos alguns índices de preços exibiam uma desaceleração promissora ${ }^{34}$ — levou as autoridades econômicas a se engajarem num entrevero estridente com os bancos privados, acusados de manterem um comportamento em dissonância com os esforços governamentais de redução da inflação. Delfim Netto acusaria publicamente os banqueiros de terem "se encastelado num mundo à parte, preferindo erguer monumentos de ferro e cimento, ingressando na especulação imobiliária para construir uma Wall Street subdesenvolvida na Avenida Paulista, para escárnio da indústria, comércio e agricultura, cujas necessidades eles ignoram".35

A disputa desaguou na Resolução no 114, do Banco Central, de 07/05/69, estipulando:

(a) taxas máximas de juros que os estabelecimentos bancários poderão cobrar em suas operações ativas a partir de 01/06/69: 1,8\% a.m. sobre operações comerciais de prazo até 60 dias, 2,0\% a.m. sobre operações comerciais de prazo superior a 60 dias e 2,2\% para outros tipos de operações;

(b) concede aos estabelecimentos de crédito que adotarem as taxas de $1,6 \%$ a.m. até 60 dias de prazo e 1,8\% a.m. acima de 60 dias para as aplicações comerciais a faculdade de compor até o limite de 50\% os seus depósitos compulsórios junto ao Banco Central em ORTN;

(c) veda o abono de juros sobre depósitos a vista pelos estabelecimentos bancários comerciais a partir de 01/06/69 e fixa tarifas máximas para a cobrança por serviços prestados pelos bancos comerciais;

(d) proibição formal da prática de "retenção de parcela do empréstimo" (reciprocidade). ${ }^{36}$ 
Uma vez atingido um desfecho satisfatório, Delfim Netto aclararia as razões oficiais para tanto barulho em torno da questão:

O Governo não tem nenhuma restrição a que bancos — ou quaisquer outras empresas - obtenham grandes lucros em seus balanços. Nossa restrição reside no fato de o setor bancário vir operando a custos crescentes. Então, quem não quiser absorver custos vai ter que engolir os lucros. A meu ver, existia um erro de perspectiva quanto à marcha dos preços este ano e ninguém parecia interessado em aprimorar as práticas operacionais, numa atitude típica de quem joga na inflação. Com a correção dessa perspectiva, os bancos vão poder operar a taxas mais baixas e o setor empresarial vai poder respirar. $^{37}$

O Banco Central também estabeleceu, pela Resolução no 115 , a redução de $12 \%$ no custo final das operações realizadas por financeiras e bancos de investimento, a ser adotada a partir de 15 de junho. Esta medida, porém, não parece ter redundado em resultados concretos, o que obrigou o Banco Central em inícios de 1970 a adotar novas medidas objetivando uma efetiva redução no custo das operações dessas instituições. ${ }^{38}$

O tabelamento das taxas de juros num sentido baixista deve ser apreciado de uma perspectiva mais ampla. De início discretamente e um pouco mais à frente (em 1971-1972) de forma explícita, uma estratégia de fomento da concentração bancária e financeira constituiu uma peça importante da política econômica delfiniana durante o "milagre" brasileiro. Por suposto, a tendência à concentração deriva da própria dinâmica do sistema. Contudo, dificilmente se poderá afirmar que a aceleração da concentração verificada no período se deveu exclusivamente às forças naturais da concorrência. Por trás do processo, atuando como seu impulsionador fundamental, existiu um projeto de política econômica. Tal projeto é expressão do peso que as frações empresariais bancárias lograram alcançar, sendo indiscutível o superfavorecimento do grande capital bancário pela política econômica conduzida em nome da redução das taxas de juros. A política de tabelamento das taxas de juros com suas recorrentes revisões operaria como um dos mecanismos inscritos nesse propósito maior. ${ }^{39}$

Esse projeto continha uma dimensão mais profunda que a simples busca de uma maior eficiência operacional do sistema bancário (associada a uma maior escala). Com efeito, durante o "milagre", a concentração bancária, ao 
se fazer pari passu com o processo de centralização financeira sob a égide do grande capital bancário, daria nascimento à figura do conglomerado financeiro. Tal entidade, a partir de certo momento, passa a ser apontada como o primeiro degrau para a formação de um verdadeiro conglomerado financeiro-industrial: a réplica brasileira do zaibatsu (ou keiretsu) japonês é peça fundamental para assegurar a consolidação do desenvolvimento e a plena constituição da Nação. A proposta da conglomeração constitui um enigma da política econômica da ditadura; existem indicações, porém, de que o seu primeiro lançamento oficial, em círculo restrito, date de $1969 .{ }^{40}$

\subsection{A condução das políticas fiscal e monetária}

A mudança de orientação da política econômica durante a maior parte de 1969 é bem ilustrada observando-se o comportamento do déficit orçamentário numa base mensal (tabela 1). De janeiro a outubro, apenas em dois meses (maio e junho) o déficit assumiria uma magnitude um pouco mais avultada, mas ainda assim inexpressiva em face dos montantes correspondentes a 1968. E enquanto em 1968 a evolução do déficit é sempre ascendente e com uma marcada concentração no primeiro trimestre (cerca de $60 \%$ do total), em 1969 o déficit somente torna-se significativo nos dois meses finais do ano. Por fim, apesar de a meta para o ano ter sido ultrapassada, uma redução substancial no déficit orçamentário foi efetivamente obtida.

Tabela 1: Déficit fiscal do Tesouro - valor acumulado (Cr\$ milhões)

\begin{tabular}{|c|c|c|}
\hline & 1968 & 1969 \\
\hline Janeiro & 287 & -28 \\
\hline Fevereiro & 417 & 77 \\
\hline Março & 732 & 35 \\
\hline Abril & 716 & 17 \\
\hline Maio & 605 & 199 \\
\hline Junho & 882 & 260 \\
\hline Julho & 924 & 53 \\
\hline Agosto & 984 & -77 \\
\hline Setembro & 1.027 & -25 \\
\hline Outubro & 1.040 & -81 \\
\hline Novembro & 1.000 & 304 \\
\hline Dezembro & 1.227 & 756 \\
\hline
\end{tabular}

FONTE: APEC, Carta Mensal, 12/12/69 e 12/02/70. 
Tendo em vista o diagnóstico oficial, a execução orçamentária durante 1969 harmoniza-se perfeitamente com o objetivo de redução expressiva da inflação dado que, até novembro, a sua tendência próxima ao equilíbrio elimina tanto um eventual excesso de demanda quanto a pressão sobre o ritmo de expansão dos meios de pagamento que até então costumava exercer. ${ }^{41}$

É também muito sugestivo o exame da discrepância entre o que foi realizado e o que fora previsto no orçamento (tabela 2).

Chama atenção o estrito controle exercido sobre a despesa até outubro, sendo que nos primeiros meses do ano ela se situa continuamente em um nível bem inferior ao programado. Isso apesar de a receita ter exibido um desempenho oposto, suplantando largamente a previsão original. Pareceme não haver dúvida no tocante ao empenho e à firmeza com que se buscou efetivamente sanear as contas do Tesouro, numa demonstração de que as intenções proclamadas logo após o AI-5 não eram apenas retóricas. ${ }^{42}$

Quanto à condução da política monetária, observou-se em 1969 uma substancial desaceleração na taxa de expansão dos meios de pagamento e dos empréstimos ao setor privado, numa indicação muito clara de que as intenções anunciadas logo após o AI-5 eram para valer. Aliás, o discurso delfiniano nessa conjuntura não se distingue da ortodoxia do governo Castello Branco: enfatizando a correlação entre expansão monetária e inflação evi-

Tabela 2: Tesouro Nacional: execução orçamentária - 1969 (Cr\$ milhões)

\begin{tabular}{lcccccc}
\hline & \multicolumn{3}{c}{ Realizado } \\
\hline Janeiro & Receita & Despesa & Déficit & Receita & Despesa & Déficit \\
\hline Fevereiro & 878 & 1.139 & -261 & 868 & 840 & 28 \\
\hline Março & 1.772 & 2.265 & -493 & 1.851 & 1.928 & -77 \\
\hline Abril & 2.537 & 3.411 & -874 & 3.042 & 3.077 & -35 \\
\hline Maio & 3.577 & 4.480 & -903 & 4.100 & 4.117 & -17 \\
\hline Junho & 4.880 & 5.654 & -774 & 5.287 & 5.486 & -99 \\
\hline Julho & 5.655 & 6.648 & -993 & 6.348 & 6.607 & -260 \\
\hline Agosto & 6.873 & 7.838 & -965 & 7.780 & 7.833 & -53 \\
\hline Setembro & 8.000 & 8.953 & -953 & 8.947 & 8.870 & 77 \\
\hline Outubro & 9.320 & 10.227 & -907 & 10.124 & 10.100 & 24 \\
\hline Novembro & 10.500 & 11.333 & -833 & 11.501 & 11.420 & 81 \\
\hline Dezembro & 11.839 & 12.587 & -748 & 12.758 & 13.062 & -304 \\
\hline
\end{tabular}

FONTE: Apecão, 1969: 36.

Obs.: A programação seria posteriormente alterada para um déficit de $\mathrm{Cr} \$ 800$ milhões. 
denciada pelos dados relativos a diferentes países, Delfim concluiria que as taxas de expansão monetária observadas no Brasil constituiriam "puro desperdício", produzidas pelo "simples desrespeito às regras básicas da política monetária, fiscal e salarial", traduzindo-se em uma "política fiscal leniente" e uma "política monetária complacente". Ao assumir a tarefa de rebater a crença de que a "inflação produz o desenvolvimento", Delfim imaginava persuadir a sociedade a aceitar a opção traçada para 1969, qual seja, "uma política monetária suficientemente realista e flexível, que reduza o ritmo de expansão da oferta monetária a limites compatíveis com as necessidades reais da economia e do nível de preços estimado". 43

O "realismo" e a "flexibilidade" da administração da política monetária durante 1969 devem ser avaliados à luz dos dados (tabela 3). Enquanto em 1968, após uma retração no começo do ano de caráter reconhecidamente sazonal, as emissões de papel moeda experimentam um crescimento contínuo, possibilitando uma razoável expansão da liquidez real de abril a outubro (e uma grande expansão no final do ano, de natureza sazonal), em 1969 não se observa qualquer emissão até julho, tornando lenta e irregular a expansão da liquidez real (e com a aceleração da inflação a partir de julho, praticamente cessa a expansão da liquidez real nos meses de julho a outubro). Também os empréstimos bancários exibem um comportamento mo-

Tabela 3: Variação mensal acumulada das emissões de moeda, dos meios de pagamento, do IPA (oferta global) e do IGP (disponibilidade interna)

\begin{tabular}{lccccccc}
\hline & Papel moeda emitido & \multicolumn{2}{c}{ Meios de pagamento } & \multicolumn{2}{c}{ IPA (oferta global) } & IGP (disp. interna) \\
\hline & 1968 & 1969 & 1968 & 1969 & 1968 & 1969 & 1969 \\
\hline Janeiro & $-2,9$ & $-7,9$ & $-0,5$ & $-1,3$ & 3,7 & 1,8 & 1,7 \\
\hline Fevereiro & $-1,5$ & $-5,9$ & 3,2 & $-0,1$ & 6,5 & 2,9 & 3,5 \\
\hline Março & $-1,5$ & -4 & 9 & 4,1 & 8,9 & 2,5 & 4 \\
\hline Abril & 2,5 & -2 & 15,2 & 5,7 & 10,3 & 3,8 & 5,2 \\
\hline Maio & 4 & -2 & 16,7 & 7,7 & 11,5 & 4,6 & 6,4 \\
\hline Junho & 6,8 & 0 & 19,8 & 11,9 & 13,8 & 7,4 & 8,7 \\
\hline Julho & 8,2 & 0 & 19,3 & 9,9 & 15,6 & 9,5 & 11,6 \\
\hline Agosto & 9,7 & 3,9 & 23,8 & 13,6 & 16,7 & 12 & 13,3 \\
\hline Setembro & 13,6 & 3,9 & 29 & 17 & 19,4 & 16,4 & 15,6 \\
\hline Outubro & 15 & 5,9 & 30,7 & 18,4 & 22,4 & 19,7 & 18,5 \\
\hline Novembro & 23,4 & 11,8 & 35,9 & 24,3 & 24,6 & 21,7 & 20,2 \\
\hline Dezembro & 41,4 & 25,6 & 43 & 32,8 & 24,1 & 21,6 & 20,2 \\
\hline Fonte: Conj & 15 & & & & & & \\
\hline
\end{tabular}

Fonte: Conjuntura econômica, dez./70, e APEC, carta mensal, 12/01/70. 
derado em 1969, sobretudo durante o primeiro semestre. O contraste com o período 1967-1968, dominado pela heterodoxia, é evidente.

Não resta dúvida que a política econômica efetivamente perseguiu a disciplina monetária, ainda que não se dispusesse a implementar um choque (como ocorrera em 1966). ${ }^{44}$

As tensões criadas por essa política econômica junto ao empresariado obrigaram as autoridades econômicas a implementarem recorrentes medidas tópicas na tentativa de abrandar as pressões de frações empresariais em dificuldades, sem abandonar porém as diretrizes centrais de austeridade e disciplina. Assim, ao lado da regularização de pagamentos em atraso de alguns Ministérios e de empreiteiras credoras do DNER, da criação de uma linha especial de redesconto para o Nordeste e da antecipação de linhas especiais de redesconto para a comercialização das safras agrícolas, destacamse como medidas destinadas a conter uma crise de liquidez incipiente no início do ano:

(1) a dilatação do prazo estabelecido para os bancos comerciais direcionarem obrigatoriamente $10 \%$ de seus depósitos ao crédito rural;

(2) a permissão para que as financeiras renovassem suas operações de capital de giro;

(3) a abertura de uma faixa especial de redesconto, permitindo expandir as operações de financiamento de capital de giro durante os meses de março e abril. ${ }^{45}$

Um outro instrumento acionado em seguida foi a extensão do prazo de recolhimento de impostos indiretos (e em casos localizados, inclusive a redução de alíquotas): a Portaria GB-112, de 08/04/69, concedeu o benefício para a indústria siderúrgica; a Portaria GB-154, de 13/05/69, beneficiou as indústrias de tecidos e calçados; por fim, a Portaria GB-226, de 25/06/69, generalizou o benefício para praticamente todo o parque industrial, concedendo em média 75 dias para o recolhimento do IPI. Tenha-se em conta que esta última Portaria, na avaliação de Delfim Netto, representaria um aporte de recursos para as empresas em torno de Cr\$ 200 milhões. ${ }^{46}$ No início de julho, o Banco Central instituiria uma faixa especial de redesconto destinada ao atendimento de empresas de porte reduzido; em agosto foi ampliado o redesconto destinado ao financiamento de exportações de manufaturados (Resolução no 71, modificada agora pela Resolução no 122) e reduzido em 
10\% o depósito compulsório (Resolução no 123 ), projetando uma injeção de recursos da ordem de Cr\$300 milhões. ${ }^{47}$

Os últimos meses do ano correspondem a um período de crise política e ao início de um novo governo, observando-se uma expansão acentuada do déficit orçamentário, dos meios de pagamento e do crédito bancário, numa conjuntura marcada por sinais de estagnação (em vez de excitar-se "sazonalmente", como é usual). Sintomaticamente, uma das primeiras medidas do governo Médici consistiu no adiamento do imposto de renda devido pelas pessoas físicas em novembro/dezembro para fevereiro/março de 1970, procurando assim estimular o consumo familiar no fim do ano (Portaria GB-424, de 03/11/69). O importante é não perder de vista que a mera observação dos dados anuais termina obscurecendo a forma de condução da política econômica durante 1969, não permitindo uma apreensão correta de sua real natureza.

\subsection{Resultados}

Não resta dúvida que a redução da inflação se constituiu na grande meta da política econômica durante 1969. E os meios utilizados na perseguição desse objetivo não diferiram muito do prescrito pelo receituário convencional: drástica redução do déficit orçamentário, disciplina monetária e creditícia, manutenção da política salarial com seu conhecido caráter restritivo. Sobre este último aspecto basta indicar que os reajustes salariais de 1969 foram arbitrados supondo:

(1) um resíduo inflacionário fixado em $15 \%$ no primeiro semestre e reduzido para $13 \%$ no segundo semestre;

(2) um coeficiente de aumento da produtividade no reduzidíssimo nível de $2 \%{ }^{48}$ Como componente heterodoxa da política econômica teríamos a querela com o sistema bancário resultando na imposição do tabelamento das taxas de juros. É possível também especular que a ação do CIP tenha sido mais rigorosa em 1969, como se depreende da observação do fato de o número de empresas punidas ter sido muito maior que nos demais anos do "milagre" (à exceção de 1973, quando a redução da inflação voltaria a ser prioridade) ${ }^{49}$

Durante o ano são recorrentes as queixas de setores empresariais acusando em maior ou menor medida os efeitos da restrição de crédito - enquanto as dificuldades, já antigas, de algumas indústrias são intensificadas. As di- 
Tabela 4: Evolução da inflação (\%)

\begin{tabular}{lllll}
\hline & IGP/D.I. & IPA/O.G. & ICV/GB & ICC/GB \\
\hline 1968 & 25,4 & 25 & 24 & 32,3 \\
\hline 1969 & 20,2 & 21,8 & 24,3 & 12,3 \\
\hline
\end{tabular}

Fonte: APEC (julho de 1970).

ferentes medidas listadas no item anterior expressam a resposta da política econômica às pressões que foram se formando no curso da implementação da austeridade fiscal e disciplina monetária. ${ }^{50}$

O comportamento dos índices de preços é decepcionante, para dizer o mínimo (tabela 4). Dificilmente se poderá argumentar que a redução do IGP - em grande parte explicada pelo comportamento do ICC, num ano caracterizado por um baixo desempenho desse setor - constituiu um "ataque mortal” à inflação como anunciado no início do ano. O ICV — alvo maior das atenções - permaneceria inalterado, alimentando uma sensação generalizada de fracasso da política de estabilização.

Enquanto os espíritos ortodoxos, agora pregando no deserto, passam a solicitar um tratamento de choque, Delfim Netto debitaria o fracasso colhido em 1969 à crise política e ao mau desempenho da oferta agrícola, continuando a defender uma opção gradualista. Aos críticos ortodoxos ele responderia:

Muitos dos que advogam esse tratamento não puderam adotá-lo quando tinham influência no governo; a experiência de outros países não prova que o resultado seja melhor que o tratamento gradualista. Na maioria dos casos provocou tensões sociais graves que acabaram jogando por terra todo um programa e criando nova aceleração na taxa de inflação. (...) Mas nós não vamos sacrificar o objetivo do desenvolvimento econômico apenas para ficar na História como o homem que acabou com a inflação a ferro e fogo. ${ }^{51}$

Na verdade, com o início do governo Médici a política econômica havia experimentado uma nova inflexão. A modéstia até então dominante (expressa, por exemplo, no PED) dá lugar a uma notável ampliação das ambições político-econômicas. Delfim Netto captaria muito bem o novo clima, propondo como meta central do novo governo uma taxa de crescimento de $9 \%$ ao ano e a conseqüente duplicação da renda per capita na década de 1970. Começara, então, o "milagre", sepultando por um longo período qualquer aventura de estabilização. 


\section{CONSIDERAÇÕES FINAIS}

Este artigo mostrou como o diagnóstico formulado por Delfim Netto em 1967-1968 afastou-se claramente da visão ortodoxa conforme expressa no PAEG. Independentemente dos traços que assinalam uma linha de continuidade, um relato adequado da política econômica da ditadura deve ser capaz de identificar as inflexões experimentadas em sua trajetória. A inflexão de 1967 já havia sido reconhecida pela literatura — por exemplo, Fishlow (1973). Ainda assim, para além de seu interesse intrínseco, é importante revisitar o tema tendo em vista que a ortodoxia do PAEG, anacrônica a seu tempo (época do "consenso keynesiano"), veio a tornar-se canônica nos últimos anos, trazendo em seu bojo o impasse melancólico da estagnação econômica (no Brasil de FHC - e, surpreendentemente, de Lula).

Por suposto, não se trata de sugerir a reprodução do passado, como se fora um paraíso perdido (sabidamente não foi o caso e este artigo procurou enfatizar descontinuidades da política econômica que sugerem antes um grau de incerteza e experimentação muito acentuados em sua execução), e sim buscar lições da história político-econômica para enfrentar o totalitarismo das abordagens pretensamente técnicas e competentes. Não se perca de vista o alcance do episódio: 1966 encerrou-se com uma inflação em alta e muito distante da meta perseguida por aqueles que afirmavam desconhecer caso de desenvolvimento com inflação; não obstante, em vez de mais remédio ortodoxo, a política econômica expandiu fortemente a liquidez e o crédito e aceitou um maior déficit orçamentário. Seguiu-se a retomada do crescimento com a inflação estabilizada num patamar mais baixo. Como apontado por Pastore, não havia certeza alguma de que esse seria o resultado; como observa Lessa, com perspicácia, o clima político, inclusive interno ao regime, tornava imperativa uma mudança de rumo - enfim, a política econômica é essencialmente política, mediação de interesses.

Como avaliar a execução da política econômica em 1969? O objetivo da desinflação efetiva volta ao primeiro plano como em 1964-1966. É verdade que o tabelamento de juros não integra o cânone; mas não é menos verdade que a execução das políticas fiscal e monetária foi rigorosamente ortodoxa. Novamente sobressai a determinação política: a conjuntura deflagrada pelo AI-5 suscita recolocar o objetivo original da política econômica do regime em foco; e abre uma perspectiva de melhores condições para a sua realiza- 
ção - veja-se a distribuição desequilibrada do ônus da redução do déficit orçamentário, conseguida por meio do AC-40. E ainda uma vez os resultados alcançados foram no mínimo precários. Notável, porém: com o advento da presidência Médici, novamente são postergadas as preocupações obsessivas com a inflação e, diferentemente dos dois governos anteriores, colocase o objetivo do desenvolvimento pleno expresso no projeto Brasil Grande Potência - mais uma vez indicando a dimensão política (e ideológica) do processo político-econômico. O novo projeto coincidiu com a percepção de que a economia brasileira entrara numa rota de crescimento acelerado — enfim, a descoberta oficial do "milagre" brasileiro. Este artigo buscou apresentar uma reconstituição pormenorizada daquela inflexão ocorrida após o AI-5.

\section{NOTAS}

1. "A inflação, asseguravam as fontes oficiais, subvertia a ordem e a hierarquia social; desorganizava o mercado de crédito e de capitais; distorcia o mercado cambial; mascarava os coeficientes de rentabilidade através de lucros ilusórios; desestimulava os investimentos nos setores de base; penalizava os investimentos do mercado imobiliário, ensejando um grave desequilíbrio habitacional; dissolvia a função orientadora do sistema de preços, premiando a especulação e a ineficiência, ao mesmo tempo em que incentivava a escalada do estatismo" (Almeida, 1980: 2). Lessa (1998: 64) sintetiza a percepção ortodoxa nos idos de 1964: "A estatização resultante distorcia o livre jogo das forças de mercado com perda geral de eficácia micro e macroeconômica. (...) A Nação poderia prescindir da estatização — terapia ineficiente — ao enfrentar a inflação em seu núcleo. A restauração do livre jogo das forças de mercado garantiria a longo prazo o crescimento auto-sustentado."

2. Ver especialmente Lessa (1998: 62-76).

3. Para uma excelente reconstituição da política econômica durante o PAEG, ver Sochaczewski (1980: 251-295). Não se deve perder de vista que o governo Costa e Silva representou a continuidade do regime, porém oposição ao grupo de Castello Branco — ver, por exemplo, o depoimento de Geisel em D’Araujo e Castro (org., 1998: 185-202).

4. Delfim Netto (1967: 1).

5. Delfim Netto (1967: 3).

6. Delfim Netto (1967: 2).

7. Após um ano à frente da condução da economia, Delfim explicitaria uma postura crítica contundente em relação ao PAEG ao afirmar: "Em março de 1967, portanto, as condições existentes para permitir a obtenção de resultados mais favoráveis nos campos da inflação e do desenvolvimento não eram mais favoráveis que no passado. A economia encontrava-se deprimida e os níveis de demanda bastante reduzidos. Primeiramente 
porque os investimentos privados haviam declinado em razão da própria estagnação da economia. Os salários reais, por outro lado, declinaram em razão da aplicação inadequada do resíduo inflacionário às fórmulas de correção salarial e o nível de emprego apresentava-se mais reduzido que nos anos anteriores, diminuindo ainda mais o volume da folha real de salários. Finalmente, a demanda no interior apresentava-se bastante deprimida em função das quedas no volume de produção ocorridas ao longo do ano" (Delfim Netto, 1968: 7).

8. Segundo Delfim Netto (1968: 4): "Para que qualquer uma dessas condições se realize, torna-se necessário que a economia não apresente as oscilações conjunturais que a têm caracterizado nos últimos anos. As perdas derivadas da capacidade produtiva não utilizada distorcem as expectativas dos empresários quanto aos retornos que eventualmente derivam da atividade e reduzem seus recursos próprios, diminuindo a disponibilidade de fundos para o financiamento das operações correntes e dos próprios investimentos. Finalmente, em uma conjuntura com alternativas de fases de prosperidade e depressão, são menores as perspectivas de uma ampliação firme da produção nos anos futuros. O resultado é que os investimentos são desestimulados, reduzindo-se a capacidade de crescimento da economia." A avaliação ortodoxa encontra-se em Simonsen (1970: 1819). Para ele, na raiz do abandono prematuro da ortodoxia estava a influência irresistível da "dinâmica imediatista".

9. Por exemplo, na seguinte formulação: "O fato de o Brasil ter vivido na década dos anos cinqüenta um período caracterizado por elevadas taxas de desenvolvimento econômico aliadas a uma inflação elevada conduziu muitos ao julgamento precipitado de que a inflação poderia criar estímulos à acumulação de capital, conduzindo a taxas mais altas de desenvolvimento econômico. (...) A experiência vivida por inúmeros países, que como o Brasil estão engajados em programas de aceleração do desenvolvimento econômico, tem demonstrado que não existem razões para acreditar que a inflação acelere o ritmo de crescimento do produto real. (...) De qualquer forma, a teoria econômica sugere e os dados empíricos confirmam a sugestão de que se existe uma correlação entre inflação e desenvolvimento, essa correlação é negativa" (Delfim Netto, 1968: 2). Essa linha de argumentação já havia sido utilizada por Delfim anteriormente, em sua crítica a Dias Leite por ocasião do debate em torno do PAEG — ver Consplan (1965) — e seria reiterada em diferentes oportunidades, como em seu artigo "Verdade cambial e inflação" ( O Estado de São Paulo, 13/10/68).

10. Delfim Netto (1968: 4-5). No artigo "Onde reside a realidade nacional" (O Estado de São Paulo, 18/04/68) Delfim também explicitava o objetivo de evitar "as alternâncias de recessão e expansão que caracterizaram a economia brasileira na última década e que terminaram por inibir todo o processo de crescimento deste País".

11. É sugestiva, a respeito, a seguinte observação de Pastore (1973): "Provavelmente alertados para o fato de que os economistas têm uma estranha predileção por combater a 'inflação errada', e com a consciência de que erros de política econômica que gerassem recessão seriam intoleráveis em um país que já por duas vezes, e em um curto espaço de tempo, estivera exposto a quedas no nível de atividade, os responsáveis pela política econômica tomaram uma atitude cautelosa. Se a 'verdadeira inflação' fosse de demanda, e eles a combatessem como se fosse predominantemente de custos, os resultados seriam 
apenas uma inflação um pouco maior do que a desejada. Se, entretanto, a 'verdadeira inflação' fosse de custos, e eles a combatessem como inflação de demanda, fatalmente teríamos uma recessão. Antes de um compromisso teórico em face de um esquema explicativo da inflação, atribuo essa posição cautelosa do governo à conseqüência de um exercício de decisão na incerteza, em que se procurava maximizar os resultados benéficos para a redução da inflação sob a restrição de evitar o aparecimento de uma recessão indesejável." Para um aprofundamento dessa questão, ver Lessa (1998: 62-76).

12. Esse argumento foi usado repetidas vezes por Delfim. Sobre a execução da política fiscal em 1967 ele diria: “Como se observa, o Governo realizou uma espécie de política compensatória de demanda, aumentando a demanda do setor público no momento em que a economia se encontrava deprimida, e reduzindo-a no momento em que a economia se recuperava e crescia a demanda derivada da ampliação dos dispêndios do setor privado. É claro que essa estratégia tem de ser aplicada com certo cuidado. Se o Governo não obtiver sucesso em contrair seus dispêndios no momento em que se ampliam as tensões derivadas do aumento da produção, a expansão de meios de pagamento pode ser bastante elevada, podendo acarretar uma aceleração das taxas de inflação" (Delfim Netto, 1968: 31). Em 1968 a execução da política fiscal teria obedecido ao mesmo padrão: ver a sua entrevista em Visão (31/01/69). Os números da execução fiscal nesse período encontram-se na tabela 2: é notável o contraste entre o padrão observado em 1966 e no biênio 1967-1968.

13. “Logo ao início da recessão, reduziu-se a demanda de crédito junto ao setor bancário em razão, basicamente, da inexistência de títulos legais representativos de operações de vendas, e que pudessem ser descontados no sistema bancário. (...) É claro que se a produção aumentasse poderia ocorrer uma demanda maior de recursos das empresas junto aos bancos, e estes estariam habilitados a fornecer os empréstimos em razão de excesso de encaixe existente. Como se sabe, entretanto, existe uma defasagem entre o momento em que são realizados os pedidos para novas vendas e o ato final de produção. Durante essa fase as empresas não possuem formas de financiar as atividades de produção, pois ainda não foram gerados documentos legais que possam ser conduzidos ao sistema para permitir a apropriação dos recursos pelas empresas e seria necessário, àquela altura, descobrir uma forma de superar essa dificuldade. Se as empresas dispusessem de capital de giro suficiente para o financiamento de suas operações, estaria resolvida a questão de compatibilizar os aumentos da demanda com o crescimento da produção a uma taxa reduzida de aumento dos preços. Isso foi feito com a postergação do recolhimento do Imposto sobre Produtos Industrializados, que deixou nas mãos das empresas cerca de Cr\$ 300 milhões” (Delfim Netto, 1968: 25-26).

14. Ver o artigo de Ernane Galveas, "Combatendo a Inflação” (Revista de Finanças Públicas, abril de 1969). Ver também os artigos de Delfim, em que recusa explicitamente a opção de aperto monetário para enfrentar a inflação, publicados em O Estado de São Paulo (18/04/68) e na Revista de Finanças Públicas (junho de 1968).

15. As manifestações de Delfim a respeito sempre foram discretas. Ver Delfim Netto (1968: 11-12) e a seguinte passagem do artigo "Onde reside a realidade nacional" (O Estado de São Paulo, 18/04/68): "Poder-se-ia perguntar por que mais controles de preços em lugar de uma política monetária mais restritiva. A resposta é simples: o governo já mostrou 
que dispõe de instrumentos de controle de expansão dos meios de pagamento e está disposto a utilizá-los quando isso se torna imperioso (...). O que não se deseja é traumatizar o sistema produtivo em resposta ao comportamento inflacionário de alguns setores onde a oferta é mais inelástica ou onde um poder de coalizão entre as empresas é mais forte."

16. Ver “Expansão continuará em 69?” (Mundo Econômico, jan./69), "Evolução da conjuntura econômica em 1968" (Boletim Mensal no 14, da Assessoria Técnica Conjunta MF/BC), ANPES: boletim trimestral (1968), Suzigan et al. (1974) e Sochaczewski (1980).

17. Em entrevista a Visão (31/01/69), Delfim observaria: "Se usarmos a linguagem fria dos números para demonstrar que ao crescermos $7 \%$ ao ano somente dobraremos o produto no curso de uma geração, é provável que nos recebam friamente e que muitos se impacientem. A demonstração de que o crescimento de $5 \%$ ou $6 \%$ já é uma performance duríssima de atingir não satisfaz quase ninguém.”

18. Na verdade, essa tese já estava discretamente presente no discurso oficial manejado em 1968. Assim, a defesa do gradualismo era atrelada à seguinte restrição: "A fim de que se crie a expectativa de efetivo declínio da taxa de inflação, é necessário que a redução seja contínua, sem oscilações bruscas (ressalvadas as influências de fatores estacionais) e que, tomado o quadriênio em conjunto (1967-1970), o declínio seja considerável, para se fazer sentido" (PED, 1968: II-5). E Delfim Netto (1968: 36) argumentava: "Em uma política gradualista, o sucesso no combate à inflação nos momentos futuros depende largamente do sucesso que se obtenha no momento presente. Se a velocidade-renda da moeda fosse constante, as taxas de inflação a cada período seriam determinadas apenas pelas taxas de crescimento dos meios de pagamento, supondo, obviamente, a constância do produto real. No caso em que a velocidade-renda depende das próprias expectativas de inflação, qualquer alteração nas taxas esperadas poderá aumentar ou reduzir a potencialidade inflacionária de uma expansão monetária.” Nesse sentido, se em 1967 a política econômica pudera regozijar-se com sua performance, os resultados colhidos em 1968 dariam margem para inquietações na medida em que colocavam em xeque a efetividade da política gradualista. A sobreveniência do AI-5 criou as condições para que tais preocupações emergissem com força, traduzindo-se em medidas concretas.

19. Entrevista a Visão (31/01/69).

20. Folha de S.Paulo (05/01/69).

21. O Programa Estratégico e os Novos Instrumentos de Política Econômica (MPCG, 1969: 9). Ver também o artigo de Ernane Galveas, "Combatendo a Inflação" (Revista de Finanças Públicas, abril/69).

22. Um aspecto no comportamento das autoridades econômicas é digno de nota: a retórica forte contra a inflação não se traduz em nenhum compromisso quantitativo - no máximo fala-se em reduzir a taxa de inflação para menos de 20\%. Apenas Hélio Beltrão se atrevia a colocar como objetivo "assestar um golpe mortal na inflação de forma a procurar derrotá-la, talvez em 69 ou 70" (Folha de S.Paulo, 05/01/69).

23. Ver de Delfim Netto: entrevista a Visão (31/01/69), artigo em Mundo Econômico (jan./69), declarações reproduzidas na Revista de Finanças Públicas (dez./68). 
24. Em sua entrevista a Visão (31/01/69), Delfim sinalizava a intensificação do esforço exportador porque "consideramos que um nível de exportações abaixo de 2 bilhões de dólares anuais é altamente insatisfatório”. Quanto às reservas internacionais, Delfim revelaria em entrevista a Veja (10/09/69) que fora estipulada uma meta de alcançar um incremento da ordem de US\$100 milhões em 1969.

25. É digna de nota a adoção do princípio da centralização administrativa, permitida pelo AI-5. Em seu artigo 10, o decreto estabelece: "A transferência de recursos da União a Estados e Municípios, nos diversos setores e sob qualquer forma, ficará condicionada à contrapartida de recursos próprios, de valor pelo menos equivalente àquele a ser transferido. A contrapartida do Estado ou Município deverá provir, preferentemente, da respectiva quota no Fundo de Participação dos Estados e Municípios." Ver O Programa Estratégico e os Novos Instrumentos de Política Econômica (MPCG, 1969: 33-34).

26. O general Albuquerque Lima, que abandona com estardalhaço o Ministério do Interior, acusaria esse decreto de "impedir uma ação dinâmica na execução de obras consideradas prioritárias e de grande interesse para várias regiões do Brasil. Para melhor apreciação, basta assinalar que a contenção imposta ao Ministério do Interior é da ordem de 33\%, contra 6\% do Ministério das Minas e Energia e 3\% do Ministério dos Transportes". Ver o seu discurso de despedida, reproduzido no Jornal da Tarde (01/02/69).

27. A justificativa oficial era a necessidade de equilibrar as finanças. Segundo a Exposição de Motivos: “(...) a perspectiva do déficit de caixa em 1969 é de considerável elevação com referência a 1968: ainda que se efetue uma contenção de Cr\$ 1.400 milhões, o déficit de caixa ainda se manteria no nível de Cr\$ 1.500 milhões. Entre as causas básicas do déficit, a perda de receita para o Fundo de Participação de Estados e Municípios (FPEM) é estimada em Cr\$ 1.800 milhões e para os incentivos fiscais, em Cr\$1.100 milhões; a soma dessas duas transferências ascende a Cr\$2.900 milhões, ou seja, 240\% do déficit programado para 1968" (O Programa Estratégico e os Novos Instrumentos de Política Econômica, MPCG, 1969: 16). O Fundo Especial seria regulamentado pelo decreto-lei no 468, de $14 / 02 / 69$, estabelecendo que pelo menos $75 \%$ dos seus recursos fluiriam para os estados do Norte e Nordeste. Os dados sobre o FPEM foram extraídos de SRF/MF (1971).

28. O dispositivo original despertou o temor de uma forte redução do imposto de renda das empresas, afetando pesadamente o volume de recursos carreados para o Nordeste através dos incentivos fiscais: ver a respeito declarações do superintendente adjunto da Sudene, reproduzidas em Visão (31/01/69). Ver também as críticas de Albuquerque Lima, reproduzidas no Jornal da Tarde (01/02/69).

29. Uma estimativa feita em 1970 sugeria que o mercado paralelo girava uma massa de recursos equivalente a 50\% do valor total dos títulos de emissão privada intermediados pelo sistema financeiro. Ver APEC (Carta Mensal, 12/06/70, p. 19). Para uma análise do mercado paralelo e de sua crise em meados dos anos 60, ver Almeida (1980).

30. A elevação da taxa de poupança, vista como uma condição fundamental para a aceleração dos investimentos e a consolidação do desenvolvimento, constituiu a motivação explícita por trás do ingente esforço de desenvolver o mercado de capitais, o qual se traduziu em formidável bateria de incentivo à formação de poupança pessoal voluntária. 
Em 1969 desenrolou-se o primeiro capítulo de um movimento especulativo na Bolsa de Valores que iria desaguar no fiasco de 1971.

31. Ver o seu discurso de transmissão de cargo no Jornal da Tarde (01/02/69).

32. Ver seu pronunciamento em encontro com o empresariado paulista em O Estado de São Paulo (28/01/69). Para uma análise política do significado desse episódio, ver Werneck Vianna (1987: 110-134).

33. Declarações reproduzidas em Revista de Finanças Públicas (dezembro de 1968, p. 53). Em seu discurso no VII Congresso Nacional dos Bancos, realizado em abril, Ernane Galveas referiu-se ao "perigo que existe quando certas práticas ocultam taxas de juros excessivamente altas e dificilmente suportáveis. (...) A exigência, por exemplo, de um saldo médio de $30 \%$ nas operações de empréstimos transforma uma taxa de juros aparentemente de 2,2\% a.m. em uma taxa efetiva de 4,0\%, que pode significar, ainda, uma taxa real de $25 \%$ a $30 \%$ ao ano, insuportável em qualquer país do mundo" ( $\mathrm{Ba}$ nas, 28/04/69). Ver também a estimativa idêntica apresentada em APEC (Carta Mensal, 12/07/69, suplemento, p. II).

34. O IPA (produtos industriais) acumulou uma alta de 6,6\% de janeiro a maio de 1969 , em comparação com 19,0\% no mesmo período de 1968. Delfim Netto chegou a exortar o empresariado paulista antevendo que "1969 representará um marco na luta secular que o País trava contra a inflação”. Ver seu discurso reproduzido em Indústria e Desenvolvimento (abril de 1969, p. 20-21).

35. Visão (09/05/69). Enquanto Hélio Beltrão se limitaria a taxá-los de "agiotas do desenvolvimento".

36. Alguns bancos passaram a operar com a taxa de 1,6\% a.m. (Bradesco, BEG, Banco Nacional de Minas Gerais, Banespa e Unibanco). Há indicações, porém, de que o sistema bancário continuou a praticar a reciprocidade, exigindo saldo médio, limitando pois o efeito esperado da Resolução. Ver APEC (Carta Mensal, 12/10/69, p. 15).

37. Visão (23/05/69). E o ministro Hélio Beltrão insistiria no ponto ao afirmar: "A batalha dos juros altos e a irregularidade do abastecimento são agora os últimos obstáculos sérios que ainda nos restam para derrotar definitivamente a inflação entre nós” ( $O$ Estado de São Paulo, 25/06/69).

38. A APEC (Carta Mensal, 12/09/69, p. 15) indicaria que algumas corretoras paulistas, por exemplo, estariam praticando um bônus de cerca de 10\% sobre as letras de câmbio, contrariando assim a disposição legal a respeito.

39. Segundo Olavo Setúbal, do Banco Itaú, o processo de concentração bancária teria se caracterizado por dupla face: "A criação de unidades muito grandes foi favorecida pelas autoridades, o que acelerou o processo. Esse favorecimento foi, basicamente, de ordem financeira e fiscal. O Banco Central permitiu determinadas vantagens fiscais para a absorção das unidades menores e menos eficientes, dentro da visão de que o sistema deveria criar unidades grandes, pela sua capacidade financeira e com possibilidade operacional e segurança financeira consideráveis. A idéia de se criarem instituições grandes também foi acelerada por uma visão de posicionamento na economia nacional. Dentro dos estritos critérios dos autores americanos, nenhuma das fusões ou incorporações foi 
acertada. Os preços pagos e os custos operacionais não permitiriam, normalmente, um aumento imediato da rentabilidade. $\mathrm{Na}$ verdade, o posicionamento numa economia com perspectivas tem sido o fator determinante. Então, há uma corrida de posicionamento, em todo o território nacional, em todas as praças e em todos os setores, a um custo, muitas vezes, de baixa rentabilidade atual, com uma visão de grande rentabilidade futura. Isso é que fez com que as instituições grandes pagassem um preço muito elevado pelas pequenas e, então, um grande número de empresas pequenas está desaparecendo, não porque elas sejam antieconômicas ou ineficientes. Elas estão desaparecendo porque as grandes instituições pagaram por elas um preço, visando a posicionamentos futuros. Teriam, teoricamente, a possibilidade de sobreviver, mas o preço é que as derrubou" (Visão, 29/04/74).

40. Ver Banas (05/05/69), Cadernos Halles no 5 e o artigo "Começa a era dos superbancos para ampliar o mercado financeiro", de Carlos Alberto Wanderley, no Jornal do Brasil (20/03/70).

41. Há uma clara mudança de enfoque em relação ao diagnóstico delfiniano de 1967-1968, quando se destacava o caráter de política compensatória da execução orçamentária - acelerando os dispêndios no primeiro semestre "no momento em que o ritmo de atividade é normalmente mais lento. Com isto se procura garantir um ritmo de 'plena carga' nos meses seguintes" (Delfim Netto, em Visão, 31/01/69).

42. O contraste com 1968 não poderia ter sido maior: naquele ano, embora a receita tenha sido igualmente subestimada (e de forma substancial), a despesa também o foi e em proporção mais ou menos semelhante, pelo menos no primeiro trimestre.

43. Ver seu artigo "Vicissitudes da política econômica no Brasil", em O Estado de São Paulo $(28 / 02 / 69)$.

44. No início de julho, Delfim defenderia publicamente o acerto dessa política enfatizando a necessidade de disciplina monetária. Descartando quaisquer críticas de que ela estaria promovendo um aperto monetário indesejável, Delfim projetava a manutenção do curso definido no final de 1968: "A julgar pelos preços no atacado, a inflação registrada até agora é da ordem de $1 \%$ ao mês, resultado que não se registra no Brasil há pelo menos uma geração. O que se pergunta neste momento é se o Governo deve alterar a política atual e pôr em risco tudo aquilo que já se conseguiu até agora em termos de equilíbrio orçamentário, disciplina do trabalho, aumento da produção e contenção da inflação.” Ver seu artigo "Perspectivas monetárias para o segundo semestre", no Jornal do Brasil, (06/07/69).

45. Ver APEC (Carta Mensal, 12/03/69, p. 11-12) e sobretudo o resumo e comentário de Banas (10/03/69), que anota: "As medidas (...) pelo menos aliviam o setor de crédito, que andava meio arrochado, provocando críticas e pedidos de socorro generalizados nos setores da indústria e do comércio (...) O mercado vai conhecer alguma folga."

46. Ver seu artigo "Perspectivas monetárias para o segundo semestre", no Jornal do Brasil (06/07/69). Para um detalhamento das portarias ministeriais, ver Conjuntura Econômica (julho de 1969).

47. Essa estimativa é citada em matéria de Veja (27/08/69). Tenha-se em conta que, ao encerrar-se o semestre, havia uma impressão muito difundida de que a política antiinfla- 
cionária estaria engendrando tendências recessivas no mínimo setorizadas. É revelador o seguinte balanço realizado pela APEC: "Existe (...) aqui e ali, grande preocupação com sinais aparentes de recessão. O gradualismo no combate à inflação absorveu e reduziu o perigo concreto e real de uma crise de imprevisíveis conseqüências econômico-políticas ao preço de pequenas recessões sazonais de intensidade e duração limitadas (...) Foi o que aconteceu em 1965, quando se passou da casa dos 90\% de inflação para a dos $40 \%$. O fenômeno se repetiu em 1967, quando da transição da taxa de $40 \%$ para a dos $25 \%$. O mesmo parece anunciar-se ao findar o primeiro semestre de 1969.” A Economia Brasileira e suas Perspectivas (julho de 1969, prefácio).

48. Ver Dez Anos de Política Salarial (Dieese, p. 28 e 36). O próprio Delfim Netto, em entrevista a Visão (31/01/69), reconhecia que o crescimento da produtividade industrial alcançara $9 \%$.

49. Ver os dados compilados por Carneiro Netto (1976).

50. Uma leitura das publicações da APEC durante o período revela a presença constante de preocupações nos meios empresariais quanto à evolução da conjuntura e os riscos de irrupção de uma crise de liquidez.

51. Ver O Estado de São Paulo (30/11/69). Para um exemplo da crítica ortodoxa, ver APEC (12/04/70). E para uma avaliação contemporânea do fracasso da política antiinflacionária, ver Anuário Banas (1970, p. 89).

\section{REFERÊNCIAS BIBLIOGRÁFICAS}

ALMEIDA, J. S. G. (1980) As financeiras na reforma do mercado de capitais: o descaminho do projeto liberal. Tese de mestrado. Campinas (mimeo).

CARNEIRO N., DIAS, D. (1976) “Política de controle de preços industriais: perspectiva teórica e análise institucional da experiência brasileira”. Aspectos da participação do governo na economia. IPEA: Rio de Janeiro. Série Monográfica n. 26.

CONSPlan (Conselho Consultivo do Planejamento) (1965) “O debate do Programa de Ação". Rio de Janeiro, Documento de Trabalho n. 3.

D’ARAUJO, M. C., CASTRO, C. (orgs.) (1998) Ernesto Geisel. 5. ed. Rio de Janeiro: Fundação Getúlio Vargas.

DELFIM NETTO, A. (1970) “Análise do comportamento recente da economia brasileira”. Documento preparado no início de 1967. Diretrizes de governo, MPCG, julho de 1967. Reproduzido pelo Curso de Economia Regional, FIPE/USP.

DELFIM NETTO, A. (1970) “Política econômica e financeira do governo”. Documento preparado no início de 1968 para uma exposição na Câmara dos Deputados em março de 1968 e reproduzido pelo Curso de Economia Regional, FIPE/USP.

FISHLOW, A. (1974) “Algumas reflexões sobre a política econômica brasileira após 1964”. Estudos CEBRAP n. 7, jan./mar., São Paulo.

FOXLEY, A. (1980) “Inflación com recesión: las experiências del Brasil y Chile”. El trimestre economico, out./dez., México. 
LESSA, C. (1998) A estratégia de desenvolvimento 1974-1976: sonho e fracasso. Campinas: Unicamp.

MALAN, P., BONELLI, R. (1976) “Os limites do possível. Notas sobre balanço de pagamentos e indústria na segunda metade dos anos 70”. Pesquisa e Planejamento Econômico, ago.

— L LUZ, J. A. (1977) “O desequilíbrio do balanço de pagamentos: retrospecto e perspectivas”. In: Carneiro, Dionísio Dias (coord.). Brasil: dilemas da política econômica. Rio de Janeiro: Campus.

MANESCHI, A. (1970) Aspectos quantitativos do setor público do Brasil de 1939 a 1968. São Paulo: IPE/USP.

MPCG (Ministério do Planejamento e Coordenação Geral) (1969) O programa estratégico e os novos instrumentos de política econômica.

MPCG (Ministério do Planejamento e Coordenação Geral) (1968) PED: Programa Estratégico de Desenvolvimento.

PASTORE, A. C. (1973) Observações sobre a política monetária no Programa Brasileiro de Estabilização. Tese de livre-docência. São Paulo (mimeo).

SIMONSEN, M. H. (1970) Inflação: gradualismo ou tratamento de choque. Rio de Janeiro: APEC.

SOCHACZEWSKI, A. C. (1980) Financial and Economic Development of Brazil, 1953-1968. Tese de doutorado. London School of Economics and Political Science, Inglaterra (mimeo).

SRF/MF (Secretaria da Receita Federal do Ministério da Fazenda) (1971) Plangef “55" (em convênio com o IPE/USP). Um aspecto da Reforma Tributária Nacional: o Fundo de Participação.

SUZIGAN, W. et al (1974). "Crescimento Industrial no Brasil - Incentivos e desempenho recente”. Relatório de Pesquisa n. 26. Rio de Janeiro: IPEA.

WANDERLEY, C. A., PIMENTEL, R. B. (1970) “O caminho brasileiro dos Bancos de Investimento". Cadernos Halles n. 5.

WELLS, J. (1973) “Euro-dólares, dívida externa e o milagre brasileiro". Estudos Cebrap n. 6 .

WERNECK VIANNA, T. M. L. (1987) “A Administração do 'Milagre”". O Conselho Monetário Nacional (1964-1974). Petrópolis: Vozes. 